Nutr. Dieta 1967;I-IV

\title{
Contents, Vol. 9, 1967
}

\section{Nutritio et Dieta}

Europäische Zeitschrift für Ernährung und Diätetik

European Journal of Nutrition and Dietetics

Journal européen de nutrition et de diététique

\section{Editores}

G. Ågren, Uppsala

R. Ammon, Homburg/Saar

E. J. Bigwood, Bruxelles

R. Boller, Wien

B. Borgström, Lund

E. Le Breton, Paris

M. Coppo, Modena

H. D. Cremer, Giessen Ch. Darnaud, Toulouse M. Demole, Geneve M. J. L. Dols, Wassenaar N. Eeg-Larsen, Oslo

F. Fidanza, Perugia

H. Glatzel, Dortmund

W. Gloor-Meyer, Zurich

J. Gontzea, Bucarest

H. Gouneixe, Paris

J. J. Groen, Jerusalem

W. Halden, Graz

C. Den Hartog, Den Haag

E. HOFF-JøRGENSEN,

København B. Isaksson, Göteborg R. Jacquot, Paris H. Kraut, Dortmund J. Kühnau, Hamburg J.

Lederer, Lou vain

F. Mancini, Roma

G. A. Martini, Marburg/Lahn

0 . Mellander, Göteborg

H. G. Mogena, Madrid H. Mohler, Zurich A. Mosse, Paris R. Nicolaysen, Oslo

G. Péquignot, Paris

F. A. Pezold, Berlin

P. Roine, Helsinki

H. Sarles, Marseille

T. F. S. M. Van Schaik, Den Haag

G. S. Schettlek, Berlin

J. C. Somogyi, Zurich

H. J. Thomasson, Vlaardingen

F. J. Traissac, Bordeaux

L. Travia, Roma 
G. P. Vecchi, Modena

G. Verdonk, Gand

F. Verzár, Basel

R. Wenger, Wien J. F. De Wijn, Zeist J. Yudkin, London

Redactores

E. Azérad, Paris

H. Kapp, Basel

J. Trémolières, Paris

K. A. J. Wretlind,

Stockholm N. Zöllner, München

1967

Vol. 9

BASEL (Schweiz)

S. KARGER

NEW YORK

INDEX

Apfelbaum, M. and Bbigant, L.: La dépense calorique de l'obèse. - Der Kaloríenverbrauch des Fettsüchtígen. - Caloric Output in Obesity

Ballester, Digna: vide Tagle, Maria Angelica.

Bonaparte, H.: vide Sdrobici, D.

Braham, J.E.; Elias, L.G.; Zaghi, S. De and Bressani,R.: Effect of Protein Level and

Duration of Test on Carcass Composition, Net Protein Utilization (NPU) and on Protein

Efficiency Ratio (PER). - Wírkung des Eíweíßgehaltes der Kost und der Versuchsdauer auf Kórperzusammensetzung, Eíweíßnutzwert und Eiweíßwírkungsgrad. - Effet du taux protéique et de la durée de Гessai sur la composition de la carcasse, Гutilisation protéique nette et le coefficient d'efficacité protéique

99

Bressani, R.: vide Braham, J. E.

Brigant, L,: vide Apfelbaum, M.

Brodan, V.; Brodanová, M.; Kuhn, E.; Kordac, V. and Válek, J.: Influence of Fruc

tose on Iron Absorption from the Digestive System of Healthy Subjects. - Wirkung von

Fruktose auf die Resorptíon von Eisen im Darm gesunder Personen. - Influence du fructose sur $\Gamma$ absorption digestive du fer de sujets normaux 263

Brodanová, M.: vide Brodan, V.

Czirbusz, G.: vide Póka, L.

Dalderup, L.M.; Voogd, N.De; Meyknecht, E.A.M. and Hartog, C.Den: The Effects of Increasing the Daily Physical Activity on the Serum Cholesterol Levels. -Die Wirkung steígender täglicher körperlicher Leístung auf den Serum-Cholesteríngehalt. - Effets de Гaugmentation de l'activité physique quotidienne sur le cholesterol du serum .... 112 Donoso, G.: vide Tagle, Maria Angelica.

Duarte, G. G.: vide Dutra De Oliveira, J. E.

Dutra De Oliveira, J.; Scatena, L. and Duarte, G. G.: Metabolic Studies on the Supp lementary Value of Animal and Vegetable Proteins. - Stoffwechseluntersuchungen über den Ergänzungswert von tíerischem und pflanzlichem Eiweiß. - Etudes métaboliques sur la valeur de protéines animales et végétales en supplementation 
Elias, L. G.: vide Braham, J.E.

Ellis, F. R. and Wokes, F.: The Treatment of Dietary Deficiency of Vitamin B12 with Vegetable Protein Foods. - Behandlung des ernährungsbedíngten Vùamin-B12-Mangels mít pflanzlichen Eiweíßträgern. - Traitement des déficiences alimentaires en vitamines B12 avec des protéines végétales 81

Földi, E.: vide Póka, L.

Gaster, Deborah ; Havivi, E. and Guggenheim, K.: Differential Effects of Low Calcium Diets on the Bones of Mice and Rats. - Unterschiedlíche Wírkungen kalzíumarmer Kostformen auf die Knochen bei Mäusen und Ratten. - Differences d'effets des regimes bas en calcium sur les os des souris et de rats 200

Ginter, E.: vide Nemec, R.

Glatzel, H.: Study on the Mechanism of Spice Effects on Stroke Volume and Stroke Frequency. - Untersuchung des Wirkungs-Mechanismus von Gewürzen auf Schlagvolumen und Schlagfrequenz. - Etude sur le mécanisme des effets des épices sur le volume et la frequence de Tondée sanguine 147

Glatzel, H. and Hackenberg, K.: Studies on the Influence of the Protein/Fat/Carbohydrate Ratio of the Diet on the Adrenocortical Function in Man. - Untersuchungen über den Eínfluß des Proteín/Fett/Kohlenhydrat-Verhältnísses der Kost auf die Nebenníeren-rindenfunktion des Menschen. - Etudes de $\Gamma$ influence des proportions respectives de protéine, lipides et carbohydrates du regime sur la fonction adréno-corticale chez Thomme 222

Guggenheim, K.: vide Gaster, Deborah.

Hackenberg, K.: vide Glatzel, H.

Hartog, C. Den: vide Dalderup, L.M.

Havivi, E.: vide Gaster, Deborah.

Isaksson, B.: The Effect of a Restricted Water Intake on the Body Composition in Young Females on Rations of Moderate of High Nutritive Value. - Wirkung verminderter Wasserzufuhr aufdie Zusammensetzung des Körpers junger weíblícher Personen bei mäßigem und hohem Nährstoffgehalt der Nahrung. - Effet d'une absorption restreinte d'eau sur la composition corporelle de jeunes femmes soumises à des rations de valeur nutritive moyenne ou élevée 183 Jastremsky, Judith A.: vide Kritchevsky, D.

Kondakis, X. G. and Laros, C.: The Ratio of Plasma Non-Essential to Essential Aminoacids in the Detection of Protein-Calorie Malnutrition in Population Groups. - Das Verhältnís níchtessentieller zu essentiellen Aminosäuren ím Plasma zum Nachweis einer Protein-Kalorien-Unterernährung in Bevölkerungsgruppen. - Rapport des acides amines non-indispensables du plasma aux acides amines indispensables et detection de la mal nutrition calorico-azotée dans des groupes humains 241

Kordac, V.: vide Brodan, V.

Kritchevsky, D.; Kritchevsky, Evelyn S.; Nair, P. P.; Jastremsky, Judith A. and Shapiro, L.L.: Effect of Free Fatty Acids on Cholesterol Metabolism in the Baboon. Wirkung freíer Fettsäuren auf den Cholesterínstoffwechsel beim Pavian. - Effet des acides gras libres sur le métabolisme du cholesterol chez le baboin 283

Kritchevsky, Evelyn S.: vide Kritchevsky, D.

Kuhn, E.: vide Brodan, V. 
Kunkel, W.: Untersuchungen über den Kalorien- und Nährstoffgehalt ganzer Großküchenessen. - Investigation into the Calorie and Nutritive Values of Canteen Meals. - Recherche sur la teneur en calories et en nutriments des repas de collectivités

Laros, C.: vide Kondakis, X. G.

Launay, Micheline: vide Raulin, Jeanne.

Lemonnier, D.: Obésité des regimes hyperlipidiques chez le rat et la souris. -Fettsucht durch fettreiche Nahrung bei Ratte und Maus. - Obesity in Rat and Mouse on High Fat Diet 27 Lygonis, C. S.: Heights and Weights of Faroese Children. - Größe und Gewicht von Kindern aufFäroer. - Tallies et poids des enfants des lies Féroé $\quad 259$

Masek, J.: vide Rath, R.

Meyknecht, E.A.M.: vide Dalderup, L.M.

Mohran, Z. Yehia : A New Method for Estimating Nicotinamide Intakes. - Neue Methode zur Erfassung der Nicotinamídzufuhr. - Nouvelle methode d'estimation des ingères en nicotinamide 177

Nair, P. O.: vide Kritchevsky, D.

Nemec, R. and Ginter, E.: The Influence of Structurally Different Fats in Diet on the Metabolism of Nucleic Acids in Irradiated Rats. - Der Eínfluß von Fetten mít verschíedenem Gehalt an ungesättígten Fettsäuren auf den Nucleinsäurestoffwechsel bestrahlter Ratten. - Influence des lipides alimentaires de différente structure sur le métabolisme des acides nucléiques chez des rats irradiés $\quad 300$

Németh Csóka, M.: vide Póka, L.

Parizková, J. and Stanková, L.: Release of Free Fatty Acids from Adipose Tissue in vitro after Adrenalin in Relation to the Total Body Fat in Rats of Different Age and Different Physical Activity. - Abgabe von freíen Fettsäuren aus Fettgewebe in vitro nach Adrenalin in Bezíehung zum Totalkörperfett von Ratten verschiedenen Alters und Körperaktivität. - Liberation des acides gras libres à partir du tissu adipeux in vitro après action de Tadrénaline rapporté au tissu adipeux total de rats d'âge et d'activité physique différents 43

Petrásek, R.: vide Rath, R.

Pieptea, R.: vide Sdrobici, D.

Póka, L.; Németh Csóka, M.; Czirbusz, G.; Földi, E. and Török, A.: The Effect of Parenteral Feeding on the Postoperative Protein Metabolism. - Wirkung parenteraler Ernährung auf den post operativen Proleínsloffwechsel. - Effet dc Гalimentation parentérale sur le métabolisme protéique post-opératoire 161

Rath, R.; Petrásek, R. and Masek, J.: Ratio of Body Fat, Cholesterolaemia, Esterified Fatty Acids and Blood Pressure of Women with Different Body-Weight. - Körperfett, veresterte Fettsäuren ím Serum und Blutdruck beí Frauen von verschíedenem Körpergewicht.

- $\quad$ Pourcentage de graisse corporelle, cholestérolémie, acides gras estérifiés et pression sanguine de femmes de différents poids corporels 67

Raulin, Jeanne et Launay, Micheline : Enrichissement en ADN et ARN du tissu adipeux épididymaire du rat par administration de lipides insaturés. - RNS- und DNS-Anreicherung ím epidídymären Fettgewebe der Ratte durch Zufuhr von ungesättigten Fetten.

- $\quad$ Increase in the DNA and RNA Content of the Epididymal Adipose Tissue in the Rat due to Administration of Unsaturated Fats 208

Sapatino, V.: vide Sdrobici, D.

Scatena, L.: vide Dutra De Oliveira, J. 
Scheggia, E. R.: Etude de Tactivité ribonucléasique dans diverses céréales. - Untersuchung der Ríbonuclease-Aktívítät in verschíedenen Getreídesorten. - Study of Ribonuclease Activity in Various Cereals 124

Sdrobici, D.; Bonaparte, H.; Pieptea, R. and Sapatino, V.: Role des catecholamines dans la mobilisation des graisses du panicule adipeux chez les obèses soumis au jeûne. Wirkung der Katecholamine auf die Fettmobílísatíon vom Fettgewebe nach Fasten beí Fettsüchtigen. - The role of the Catecholamines in the Fat Mobilization from the Adipose Tissue in Fasting Obese Patients

Shapiro, I.L.: vide Kritchevsky, D.

Stankova, L.: vide Pahizková, J.

Stroink, J.B.A.: Composition and Consumption of Dietary Fats in U.S.A., U.K. and Common Market Countries in 1961. - Zusammensetzung und Verbrauch von Nahrungsfetten in den USA, in England und in der EWG 1961. - Composition et consommation des graisses alimentaires aux Etats-Unis d'Amérique, au Royaume-Uni et dans les Pays du Marché Commun en 196156

Tagle, Maria Angelica; Ballester, Digna and Donoso, G.: Net Protein Utilization of a Casein Diet by the Pregnant Rat. - Eíweißnutzwert eíner Kaseínkost beí der schwangeren Ratte. - Utilisation protéique nette d'un regime contenant de la caséine par la rate gestante 21

Tòrök, A.: vide Póka, L.

Válek, J.: vide Brodan, V. Voogd, N. De: vide Dalderup, L.M.

Wijn, J.F.De: Nutritional Health in the Adolescent Period. - Ernältrungsbedingte Gesundheit im Jugendalter. - Bon état nutritionnel durant $\Gamma$ adolescence 1 Wokes, F.: vide Ellis, F.R.

Zaghi, S.De: vide Braham, J.E.

All rights, including that of translation into other languages, reserved. Photomechanic reproduction (photocopy, microcopy) of this volume or parts

thereof without special permission of the publishers is prohibited

(C)

Copyright 1967 by S. Karger AG, Basel

Printed in Switzerland by Lüdin AG, Liestal

Cliches: Aberegg-Steiner \& Cie., AG 